\title{
THE NATURE OF HAZARDOUS DUTY IN MILITARY DESERTION
}

\author{
Alfred Avins*
}

\begin{abstract}
A RTICLE 85(a)(2) of the Uniform Code of Military Justice ${ }^{1}$ provides that an absentee who goes AWOL to avoid "hazardous duty" is a deserter, and, in time of war, punishable with death: This threat is not mere brutum fulmen; the only American serviceman executed since the Civil War for a purely military offense was shot to death by a firing squad during World War II in Europe for a violation of this provision. ${ }^{2}$ This capital crime is therefore well worthy of precise definition, yet neither the Code itself nor the current Manual for Courts-Martial ${ }^{3}$ makes any attempt to define the term comprehensively or clearly. Indeed, the Manual's only example of "hazardous duty" is "duty in a combat or other dangerous area," the first half of which is misleading and the second half of which is redundant.

The lack of definite standards for the term "hazardous". stems in part from its introduction into the Articles of War as a novel term, without any prior military law background in the English Code, ${ }^{5}$. and it is probable that those who drafted the original statute had only the haziest ideas of its precise coverage, beyond the inclusion of combat itself. 8 This dearth of legislative background makes it feasible and desirable to approach the problem of defining the term from a common law point of view, determining what duty is "hazardous" in light of sound military policy, consistent legal reasoning, and relevant service experience.

This article will explore the military law precedents which have dealt with the problem of what constitutes "hazardous duty." From these precedents, it is believed that some rational common law standards

*A.B. 1954, Hunter College; LL.B. 1956, Columbia Law School; LL.M. 1957, New York Univ. Law School; LL.M. 1961, Univ. of Chicago Law School; J.S.D. 1962, Univ. of Chicago Law School. Associate Professor, Chicago-Kent College of Law.

${ }^{2}$ to U.S.C. $\$ 885$ (a) (2) (1958).

'ETO 5555, Slovik, 15 ETO 151 (1945).

- Manual for Courts-Martial, U.S. ARMX, 1951.

IId. at If 164 (2) (2).

Avins, A History of Short Desertion, 13 MiLitarT L. Rev. 143, 162 (196r).

'Id. at 163 .
\end{abstract}


for defining this term can be extracted which will apprise a serviceman of the standard of conduct below which he may not be permitted to fall.

\section{Military Precedents Generally}

The legislative history of article $85(a)(2)$, as noted above, shows clearly that in using the word "hazardous," the drafters of the statute intended thereby to include combat duty involving risk to life and limb from enemy fire. The point was usually treated as being so obvious as not to require discussion prior to the enactment of the code, ${ }^{7}$ and continues to be so dealt with. ${ }^{8}$ Indeed, the Court of Military Appeals has declared that it is "approaching absurdity for a member of a court not to consider [combat duty] hazardous."

The problem really arises in those cases not involving combat. In time of war, hazard may exist in special fields or operations, or it may be widespread. Activities which are not hazardous during peacetime may become exceptionally dangerous in wartime, and hazardous duty in time of peace may remain so during hostilities but for different reasons. ${ }^{10}$ It is necessary in all cases to identify the category into which the case falls.

Some statements fail to recognize the fact that whether duty is

${ }^{7}$ For typical cases, see: CM 319656 (CM P 582), Scafidi, MO-JAGA 103 (1950); CM A-I 777; Jacobsen, 2 A-P 383 (x 945); CM IBT 338, Schryver, z CBI-IBT I59 (1944); CM IBT 339, Hahn, 2 CBI-IBT I65 (1944); MTO 501 , Jarlock, 6 NATO-MTO 6I (1945); MTO 5009, Dailey, 6 NATO-MTO 57 (1945); MTO 4958, Kallas, 6 NATO-MTO 47 (1945); MTO 4957, Millican, 6 NATO-MTO 43 (1945); MTO 4689, Tucker, 5 NATO-MTO 275 (1945); MTO 4512, Campione, 5 NATO-MTO 229 (1944); MTO 4434, Elizondo, 5 NATO-MTO I85 (r945); NATO 2844, Mangerpan, 4 NATO-MTO 225 (1944).

${ }^{8}$ See United States v. Horner, 2 USCMA 478, 9 CMR 108 (1953); United States v. Young, 2 USCMA 470, 9 CMR 100 (1953); United States v. Barley-Espada, I2 CMR 358 (CM 1953); United States v. Pascal, 3 CMR 379 (CM 1952); United States v. Keller, 2 CMR 546 (CM 1952); United States v. Dittmar, 2 CMR 475 (CM 1952); United States v. LaCaze, 2 CMR 443 (CM 1952); United States v. Mercer, 2 CMR 420 (CM 1952); United States v. Melton, 2 CMR 353 (CM 1952); United States v. Brown, 2 CMR 300 (CM 1951); United States v. Sease, 2 CMR I8I (CM 1951); United States v. Mothersell, I CMR 401 (CM I951); United States v. Moynihan, I CMR 398 (CM 195r), aff'd I USCMA 333, 3 CMR 67 (1952); United States v. Fasciana, I CMR 243 (CM 195I); United States v. Chaney, I CMR 20+ (CM 195I).

- United States v. McIntyre, 2 USCMA 559, 10 CMR 57, 60 (1953). See also ETO 5117 , DeFrank, I4 ETO I63, I65 (1944) (beyond peradventure this was hazardous duty); MTO 477 I, Pack, 6 NATO-MTO I 3 (1945) (combat duty of such character was manifestly hazardous).

${ }^{10}$ Hearings Before a Subcommittee of the House Committee on Armed Services, 8ist Cong., ist Sess., ser. 47, at 1580 (1949) [hereinafter cited as I949 Hearings]. 
hazardous or not is a question of fact, albeit usually legislative or generalized fact, and assume that all military duty, especially in time of war, constitutes hazardous duty. The inadequacies of these analyses are patent. For example, one congressman remarked that "everything connected with a war is hazardous. It makes no difference where you are, ..." "11 while a Senator declared that "I know of no branch of the service, whether you are using shotguns or jet aircraft or most anything else, that isn't hazardous. . . ."12 These statements are certainly not applicable to short desertion, ${ }^{13}$ for the statute mentions "hazardous duty," and not all duty during time of war.

The above statements are both erroneous in fact and wrong in law. In infantry regiments during World War II, only a portion of the men were exposed to combat hazards, and the bulk of casualties in a division were sustained by the over four thousand riflemen. These men were exposed to "teriffic physical hardships" in addition to battle. As a result, the non-battle casualties from causes such as trenchfoot, pneumonia, and battle fatigue accounted for an average of ten percent of the total casualties per month in the line units, and were sustained principally by the fighting men. ${ }^{14}$

The cases hold the same way. In one case where accused had been assigned to an infantry company and went absent without leave from the rear command post, the board of review still commented on the failure to show the location of the post in relation to the enemy, the existing hazards at the post, or the impending hazards known to the accused. Holding that the evidence failed to show that accused went AWOL with intent to avoid hazardous duty, the board declared: "Unless we are willing to hold that assignment in any capacity to an infantry company during war is hazardous duty, and all who leave it without permission, are guilty of the cowardly offense of desertion, the case must fall. We cannot hold that proof should be so lax."1" In another case, a board of review in the Southwest Pacific Theater of Operations declared that

"while the inference properly may be drawn that he intended to avoid the normal duties of a cavalry private there is no evidence permitting this in-

\footnotetext{
${ }^{21} I d$. at 1620 .

${ }^{13}$ Hearings on H.R. 4720 Before the Senate Committee on Armed Services, 84th Cong., Ist Sess. 120-21 (1955) [hereinafter cited as 1955 Hearings].

${ }^{13}$ See Avins, $A$ History of Short Desertion, 13 Military L. Rev. 143 (1961).

${ }^{14} 1949$ Hearings at 1621 .

${ }^{15}$ ETO 15223 , Skuczas, 29 ETO 7, 9 (1945).
} 
ference to be inclusive of hazardous duties, as would be permitted if the accused or his division had been engaged in recent combat, or was about to be and the accused so knew when he went absent without leave."16

Still a third decision from the European Theater of Operations declared that "not all absences without leave from combat troops are desertion, and circumstances must be proved from which intent to avoid hazards may be inferred."17 And finally, a post-I95I decision notes that "all duty in a combat area is not necessarily hazardous."18 Thus, statements that all military duty in time of war is hazardous are erroneous if applied to this offense.

Another case attempts to define hazardous duty in terms of where the AWOL occurs. In United States $v$. Cook, ${ }^{19}$ the Court of Military Appeals was faced with a situation where a medical aid man went AWOL to avoid duty with a machine gun platoon. Since the accused undoubtedly suspected that the platoon was going into combat because it called for medical personnel, although no one was then injured, this should have been enough to uphold the finding of intent to avoid hazardous duty through unauthorized absence. The court went on to declare, however, that "hazardous duty should certainly include, at the least, such duty as would be covered by the term 'before or in the presence of the enemy' as used in Article 99 of the Uniform Code of Military Justice."20 This is much too broad, for all such duty is neither hazardous in fact nor in law.

Duty before the enemy may not be hazardous because the enemy may be too far away. Moreover, the enemy may be retreating or unable to inflict harm because of weakness. Indeed, the enemy may be surrendering, ${ }^{21}$ yet the duty of collecting prisoners of war cannot be deemed hazardous, and it has been so held. ${ }^{22}$

The problem of equating duty before the enemy with hazardous duty is brought out clearly in two World War II cases from the European Theater of Operations. In one case, ${ }^{23}$ accused was a member of the gun crew of an anti-aircraft unit stationed to give protection as

\footnotetext{
${ }^{10}$ CM A-1 925, Knapp, 3 A-P 41,44 (1945).

${ }^{17}$ ETO 15225 , Barth, 29 ETO 11,13 (1945).

${ }^{18}$ United States v. Olson, I CMR 613,616 (NCM 1953).

${ }^{10} 2$ USCMA $223,8 \mathrm{CMR} 23$ (1953).

${ }^{20} \mathrm{Id}$. at 225 and 25. See ETO 9290, Grijalva, 20 ETO 225 (1945) (involving AWOL from a medical unit under fire).

${ }^{22}$ Cf. ETO 14905, Murtha, 28 ETO 259 (1945).

${ }^{22}$ ETO 8649, Siglasky, 19 ETO $369,371-72$ (1945).

${ }^{28}$ ETO 8104, Shearer, 19 ETO 17 (1945).
} 
well as ground support to infantry units. In the other, ${ }^{24}$ the accused belonged to a similar organization providing security for an artillery unit. In the former case, accused had been for the time assigned to cook for the gun crews near the gun section and had been relieved of other duties; in the latter case he had not. The former case held that "the burden is on the prosecution to establish the intent alleged and is not discharged by a mere general showing that accused's organization engaged in some combat activities during the month in which the absence occurred."25 The latter case, on the other hand, held that since the anti-aircraft guns had engaged aircraft on several occasions, the intent to avoid hazardous duty, viz., combat with the enemy planes, was proved.

It is obvious that nothing in these cases can properly turn on the metaphysical distinction as to whether either or both accused were "before or in the presence of the enemy." If enemy bombs were falling, or the area was being strafed, both were subjected to hazards. If the enemy planes were merely flying overhead without attacking ground installations, such as if they were unarmed observation planes, and anti-aircraft guns were attempting to destroy them without return fire, then neither accused was engaged in hazardous duty although the gun crew member was engaged in combat duties and was certainly before or in the presence of the enemy. It therefore follows that as a factual matter, while many duties before or in the presence of the enemy are indeed hazardous, there is no inevitable connection between the two, and factually one does not prove the other.

Moreover, a mere showing that accused's organization was "before or in the presence of the enemy," without more, would be, as a matter of law, too vague to support an inference of intent to avoid hazardous duty. Thus, where the only showing was that at the time of accused's absence his unit was in a defensive position, the board of review held that this did not show that accused's duty was hazardous. ${ }^{20}$ In a similar case, a board said:

\footnotetext{
${ }^{24}$ ETO 6997, Jennings, i7 ETO 309 (1945).

${ }^{25}$ ETO 8104, Shearer, 19 ETO 17, 18-19 (1945).

${ }^{26}$ ETO 8708, Lee, 20 ETO 15, 17 (1945). But see ETO 8358, Lape, 19 ETO 179 (1945):

The legality of this conviction of desertion to avoid hazardous duty depends on whether or not the evidence that the company was in a "defensive position" is proof of hazardous duty then existing or imminent. Dictionary of UNITED STATES ARMY TERMS (TM 20-205) defines "defensive position" as follows:

"Area occupied by troops organized in a system of mutually supporting defense
} 
In order to sustain the findings of guilty under the present allegation of desertion, the evidence must show that the accused absented himself from his organization with the specific intent of avoiding hazardous duty with his organization at Charleston, South Carolina. The proof shows no such intent. In fact the evidence shows that the accused did not know, and had no cause to know where his organization was going, or that it was going to Charleston. Furthermore, the record presents no evidence to explain the meaning of the phrase "Sub Sector defense mission" as alleged in the specification, or to show that the service to be performed in Charleston was actually hazardous. In fact, there is a complete absence of evidence from which a reasonable inference might be drawn that the accused deserted his organization in order to avoid any dangerous service. ${ }^{27}$

In still a third case, a board declared that "the statement that he was with a 'front line organization' is too indefinite and general to show ... that accused was attempting to avoid hazardous duty."28

While the fact that the accused's unit was before the enemy would make the case stronger than the above situations, nevertheless the same rationale applies because the evidence contains the same infrmities. A mere showing that the accused is located in a particular geographical place or is performing duty with a particular kind of unit does not prove that his duty is hazardous, in the absence of a showing of additional facts or unless aided by common knowledge of which the court may take judicial notice. Hazard is a fact and is not ipso facto derived from proximity to the enemy any more than its absence may be derived from distance from the enemy.

Of course, there is no doubt about the fact, reached in the Cook case $^{2 \theta}$ via a twisted path of reasoning, that hazardous duty is not limited

areas or fortified tactical localities."

It is apparent that the term includes the position of our troops at fortified localities or other areas far removed from the scene of battle and from any imminent dauger. The phrase is meaningless as a showing of dangerous duty which the accused sought to avoid. ...

The Board of Review does not herein intend to express the opinion that the phrase "defensive position" denotes lack of hazardous duty, for it is obvious that if there were any evidence that the enemy were near, or endangering, or apt to endanger, the position, the record of trial would sustain the sentence. Id. at $181-82$.

${ }^{27}$ CM 224947, Lovette, I4 BR 2II, 2 I4 (1942).

${ }^{28}$ ETO I 2128 , Bailey, 25 ETO 45, 47 (1945). See also ETO 675 I, Burns, 17 ETO 195 (1945). "It does not follow that because a soldier absents himself without leave at the front he is ipso facto guilty of desertion of the type herein alleged." $I d$, at 199.

${ }^{20}$ See text accompanying note 19 supra. 
to the immediate area of fighting. It has been properly held that a unit maintaining a supply route to combat troops and subject to artillery fire and air raids, ${ }^{30}$ or a combat engineer company clearing and laying mines under enemy fire, ${ }^{31}$ was engaged in hazardous work. Likewise, where accused was a driver for an artillery battery supporting combat units and subjected to shelling, ${ }^{32}$ or a truck driver for an infantry company pursuing enemy forces, ${ }^{33}$ or a "motorcycle messenger . . . subject to being sent from the company headquarters to the front line platoons at any time, where the area was exposed to heavy shell fire and infiltration by enemy patrols, and where he would have to take messages by himself at any hour of the day or night, ${ }^{34}$ it was held that accused was engaged in hazardous duty. Even where accused's duties are to collect prisoners of war behind the lines ${ }^{35}$ or to engage in Graves Registration Service on a battlefield long since quiet, ${ }^{30}$ the duty is hazardous if the accused is subjected to hostile fire or the area is mined.

Duty may be hazardous, moreover, although the danger does not arise from enemy action. A pilot of a liason plane who must fly close to the ground incurs the dangers of crashing into trees. ${ }^{37}$ Likewise, a military scientist working with chemicals or atomic materials, or a test pilot, is often engaged im hazardous duty. ${ }^{38}$ These examples show that hazardous duty is not limited solely to combat.

While military cases show that the concept of hazardous activity is broader than battle duty, they do not form a logical pattern by which the concept can be generally applied. It cannot be denied that some of the above authorities are confused or conflicting, and present no uniform interpretation or application. We must therefore look further for a set of standard criteria.

\footnotetext{
${ }^{80}$ MTO 6235, Love, 6 NATO-MTO 275 (1945).

${ }^{81}$ ETO 16655, Pagano, 31 ETO 127, 129 (1947).

${ }^{82}$ NATO 2114 , Burgess, 3 NATO-MTO 373 (1944).

${ }^{88}$ ETO 5666, Bowles, I 5 ETO 307 (1945).

"ETO 11455, Sharp, 24 ETO 143, 144 (1945).

${ }^{85}$ See ETO 8649, Siglasky, 19 ETO 369 (1945).

The accused's duties, on the particular day he left, were those of Prisoner of War chaster with a battalion headquarters company. This is in itself a hazardous occupation. Operating at less than 500 yards from the actual rifle-firing infantry, he must advance and relieve the company PW chasters of their burden and guard the PWs to a collecting point from which they are evacuated to the rear. A reasonable man would certainly believe that this was a hazardous occupation, since it is carried on within easy range of automatic weapons, rifle fire and hostile mortars, to say nothing of rockets and light artillery. Id. at 372 .

${ }^{38} \mathrm{CM}$ 279399, Williams, 52 BR 201, 203 (1945).

${ }^{87} 1949$ Hearings at 1610 .

${ }^{88} I d$. at 2128,213 I.
} 


\section{Hazardous Place of Duty}

Article 85(a) (2) of the Uniform Code of Military Justice refers to "hazardous duty." This term is in many instances misleading, even when applied to combat situations, because most military duty, even in combat, is not inherently hazardous. There is nothing inherently dangerous about running across an open field; it is dangerous only when enemy machine guns are firing at the field. Manning a battalion observation post is not in and of itself hazardous; what makes it dangerous is enemy mortar fire directed at the spot where the post is. ${ }^{38}$ Fording a river is not usually an unsafe thing to do but fording a river against opposition into enemy territory is fraught with hazards. ${ }^{40}$ As one observer put it: "It was not being an infantryman that was dangerous work; it was being in the front lines."11

The above examples suffice to show that the absence without leave prohibited by article $85(\mathrm{a})(2)$ is AWOL from a hazardous place of duty, not merely AWOL from duty which is hazardous. In other words, if accused has a place of duty which is dangerous, absence without leave to avoid that place is short desertion regardless of what the accused's duties are at the place or whether they are hazardous in themselves or not.

Several military cases point up this fact. In one case where accused's company was in a defensive position under rifle and artillery fire, a board of review declared that "accused's place of duty, his duty with his company, involved hazard."12: In another case, a board said:

Immediately prior to his absence, accused's company was located at the Anzio Beachhead. It was in a reserve position but enemy shells, directed at friendly tanks, were falling in the area and enemy small arms fire was overhead. The company was in such proximity to the enemy that its very presence in the area was hazardous and the situation was such that it might evolve at any moment into active combat with the enemy. It is thus immaterial that the record lacks evidence that accused was specifically notified of the orders requiring movement of his unit to another position where it was to "go into action." 43

\footnotetext{
${ }^{30}$ United States $x$. Yingling, 5 CMR 196, 198 (CM 1952).

${ }^{40}$ ETO 13482 , Ianuzzo, 27 ETO I (1945); ETO 12619, Hatfield, 25 ETO 291 (1945); ETO 12007 , Pierce, 25 ETO I (1945); ETO 11468 , Baggett, 24 ETO 147 (1945); ETO 9469, Alvarez, 21 ETO 55 (1945); ETO 5394, Quinn, 14 ETO 385 $(19+5)$.

"1949 Hearings at 1620 .

${ }^{12}$ ETO $1462 ;$, Fassiacht, 28 ETO 119,123 (1945).

${ }^{18}$ ETO 6810, Shambaugh, 17 ETO 219, 222 (1945).
} 
Of course, some duties are inherently hazardous. One example of this would be clearing land mines, ${ }^{44}$ which may explode regardless of where they are located. Such inherently dangerous duties, however, constitute but a small minority of the hazardous duties comprehended in the concept of short desertion. Indeed, so few are these inherently hazardous activities that special mention was made in one case to show that the activity fell within the ambit of the statute. This presented the interesting spectacle of a statutory term of "hazardous duty" being so often used as a "hazardous place of duty" that when a board is finally faced with an inherently and actually hazardous duty as such, it finds that the duty falls within the statutory term of "hazardous duty" only by analogy to duty in a hazardous place. Thus, the board of review declared:

Immediately prior to accused's departure his platoon was engaged in mine removal work and was in the spearhead of the pursuit of the Germans. That such duty was hazardous will not be gainsaid. ... The situation thus presented is of the same nature as that of a typical battleline desertion case. The "enemy" which accused faced were not German soldiers in battle array but the dangerous mines planted by them on the roads to prevent and hinder the American advance. Accused had actually engaged in this highly perilous work and knew the risks involved. He left his command without authority in the midst of a hard campaign at an opportune time in order to avoid these certain future hazards. His guilt was proved. ${ }^{45}$

Now that it has been established that the concept of "hazardous duty" in short desertion includes a hazardous place of duty, this raises some problems when the accused at the hazardous place may not be doing the kind of duty for which the statute was designed to keep him there. This possibility is graphically illustrated by a case from the European Theater of Operations. ${ }^{46}$ Accused and his unit were being shelled by the enemy, which was about three or four miles away. Accused had recently returned from an unauthorized absence and was in a status of semi-confinement, awaiting trial by court-martial for his prior offense. The unit's prison guard was unable to guard both German and American prisoners and placed the latter, including accused, in an unlocked cellar without guard. When the German artillery commenced shelling the area again, "it got too hot for [ac-

\footnotetext{
"See MTO 4373, Ashby, 5 NATO-MTO I65 (1944). Cf. CM 279399, Williams, $52 \mathrm{BR} 201$ (1945).

"ETO x 2044, May, 25 ETO xx, 14 (1945).

${ }^{48}$ ETO 7339 , Conklin, 18 ETO 95 (1945).
} 
cused], so [he] became scared and left the PW without the guards seeing" him, and went without authority to the rear for the admitted purpose of avoiding enemy artillery fire. ${ }^{47}$ The question thus presented is whether accused intended to avoid hazardous duty within the meaning of the statute by leaving a prison compound under fire.

The solution of the board of review to the problem was to avoid the issue completely. First, the board observed that all units of accused's regiment were either engaged in combat or in reserve, subject to hazardous duty at the will of superior authority. It then noted that accused left the cellar, his place of duty, and went to the rear because frightened by enemy shelling. The board then jumped back to the fact that accused might have been released from confinement and ordered to perform various duties involving hazard. The board next commented that "it was accused's duty to remain in the cellar which was a hazardous place at the time. When he left he escaped existing hazards and perils of battle." Without waiting to explain what existing battle perils, as distinguished from hazards generally, accused escaped, since he was not in battle, the board again expounded on the "imminence of hazardous duty for accused, who was immediately available for its performance ... [because] as a practical matter ... for soldiers in and near the front line of battle, where manpower is always vital and a prime necessity, hazardous duty is ever present or imminent." The board finally ended with the following astounding conclusion:

It is reasonable to infer that accused knew this and that this knowledge, at least in part, motivated his departure. His duty was to remain in the cellar pending his trial and pending the assignment to him of any duty his commanding officer might see fit at any time to impose upon him. It may be concluded, therefore, that hazardous duty and important service involved in action against the enemy were, to accused's knowledge, reasonably imminent for him, that his absence was "calculated to enable him to avoid" and shirk such duty and service (MCM, 1921, par. 409, P. 344), and that he absented himself from his place of duty with intent to avoid and shirk them, as alleged. ${ }^{48}$

The record as set forth by the board contained not the slightest shred of evidence upon which to base an inference that accused was soon to be released from confinement and sent into battle, that he knew this, or that he intended to avoid battle duties. On the contrary, accused's own statements and ample other evidence showed that he went to the

\footnotetext{
"Id. at 97-98.

${ }^{48}$ Id. at 99 .
} 
rear solely because the place of confinement was being shelled. Leaving aside the utter chaos into which the opinion was thrown by such ambivalent reasoning, the board nevertheless made reasonably clear its view that if accused left his place of confinement because it became dangerous, then he was guilty of short desertion. The board's position, briefly stated, was that accused must be shot for desertion because he would not stay in confinement to be killed by shelling. ${ }^{40}$

A different aspect of the same problem is pointed up by another case from the same theater ${ }^{50}$ which appears to look the other way. In this case, accused was charged with misbehavior before the enemy by running away from his company, of which AWOL is a lesser included offense. ${ }^{51}$ Accused was in a regimental field train where men who had been hospitalized and had recovered assembled to secure transportation to their respective units. Accused met a superior noncommissioned officer of his company who was driving a truck loaded with rations back to the company's position. Accused asked for and obtained permission to ride with the sergeant, although he was not under orders to ride this specific truck. En route an enemy artillery barrage commenced. Accused desired to leave the truck but the sergeant ordered him not to do so. Further on, the truck encountered another barrage. The driver, assistant driver, and accused left the truck and took cover. When the barrage lifted, accused could not be found. Based on the above facts, a board of review held accused not guilty. It reasoned:

It is obvious that accused at the time he went absent without leave had not physically rejoined his company although administratively and on paper he was a member of Company $A$. He was under a duty to proceed to his company from the field train, but he was not ordered to become a passenger on Sucharsk's truck. He voluntarily sought transportation thereon. There was no compulsion on him to continue as passenger on the truck. In view of the fact that the road on which the truck proceeded was under enemy fire it may have been an act of prudence and not of cowardice to discontinue the journey on it and to proceed to the company by other means and by other routes. It cannot be said that accused's presence on the truck placed - him physically with his company. The truck was not the company; it was only a means by which accused could reach the company. ${ }^{52}$

${ }^{\circ}$ Cf. 2 CoKe's Institutes 590; 2 Hawkins, Pleas of the Crown, Chap. 18, Sec. 11 (recognizing the right of a prisoner to leave a prison which has been set on fire).

${ }_{B 0}$ ETO 4740 , Courtney, ${ }_{3}$ ETO 241 (1945).

${ }^{51}$ Avins, THE LAW OF AWOL 42 (1957).

${ }^{82}$ ETO 4740, Courtney, I3 ETO 241, 246 (1945). 
Here again, unwilling to face the issue squarely, the board befogged it. It started out by conceding that accused became absent without leave when he left the truck, a status manifestly impossible unless accused had a duty to remain on the truck. If, as the board contended, accused had only the duty to proceed to his organization, he would not become AWOL until a reasonable time for travel had elapsed..$^{53}$ The board then switched signals and argued that accused had no duty to remain on the truck, an entirely erroneous conclusion because accused's sergeant had ordered him to remain on the truck. Assuming arguendo that accused's status ab initio was one of leave, the sergeant, a superior noncommissioned officer, had terminated the leave. ${ }^{54}$ The board finally reached the startling conclusion that the ration truck was not a part of accused's organization from which accused could go AWOL, a conclusion quite contrary to other precedent in the same theater..$^{55}$

Of more significance is the board's observation that the accused's act may have "been an act of prudence and not of cowardice." The question of where to draw the line between these two labels for an essentially identical intent, namely, to save one's own skin, is inherent in the whole area of short desertion where intent to avoid hazardous duty is alleged, and becomes especially acute in consideration of absence without leave from a hazardous place of duty. The significance of this problem is illustrated by the constant reference in cases involving AWOL to avoid a hazardous place of duty to the "cowardly abandonment of his comrades.."56

A hypothetical situation will perhaps point the way to the solution. Suppose that there is an Air Force base located many miles from the front lines. On this base three airmen are performing assigned duty close by each other. The first airman is engaged in policing the area, i.e., picking up loose cigarette butts, wrapping papers, etc. The second is stationed at an anti-aircraft gun. The third airman is loading machine gun bullets into a fighter plane. It is clear that none of them are performing a duty inherently hazardous, nor is their place of duty a hazardous one. If any of them without authority left his place of

\footnotetext{
${ }^{88}$ Avins, op. cit. supra note 51 , at 63-65.

ic Id. at 88 .

${ }^{85}$ ETO 5437 Rosenberg, 15 ETO 9 (1945). See also ETO 5396, Nursement, 14 ETO 391 (1945).

${ }^{80}$ ETO 12951, Quintus, 26 ETO 63, 66 (1945). See also CM 228401, Webster, 16 BR 167, 171 (1943) (cowardly purpose of deserting his comrades); ETO 9857, Harrell, 21 ETO 229, 231 (1945) (cowardly offense of desertion); ETO 8610, Blake, 19 ETO 345,346 (1945) (intent was cowardly).
} 
duty, he would be guilty of absence without leave from a specific place of duty under Article 86(2) of the Uniform Code of Military Justice, and nothing more.

Now let us assume that enemy fighter planes dive from the sky and commence to strafe the airfield. The duty of none of the airmen has become any more inherently hazardous. What has become hazardous is their place of duty, made so by enemy machine gun fire. It is also obvious that the place of duty of each of the three is equally hazardous, for each is exposed to the risk of death or injury from the fire, which has an equal chance of hitting any of the three.

Suppose that each of the three, equally fearful of death from enemy fire, abandons his place of duty and takes shelter elsewhere during the attack. Each of the accused has the same intent, to avoid the hazards of his place of duty and to seek safety by leaving his post without proper authority. Thus each of the accused, facing the same hazards at the same place, went absent without permission to avoid identical hazards. Although the only difference between the three is the nature of the non-hazardous duty, it can be predicted that all military courts would make distinctions based on the nature of the duty, rather than the nature of the hazards. Yet the statute nowhere makes this a ground of difference.

Take, for example, the first airman. It is safe to predict that all military courts would acquit him, not only of desertion but also of absence without leave. Such action would not be an exercise of mercy, but would most certainly be based on sound military policy. It would be manifestly absurd to require a soldier to risk his life to collect stray cigarette butts. When the first airman takes cover we deem his act one of prudence, not of cowardice.

It is not so with the airman manning the anti-aircraft gun. He would clearly be held guilty of AWOL with intent to avoid hazardous duty or more properly, a hazardous place of duty. Military policy requires that he remain at his post of duty and attempt to protect the field by shooting down enemy planes. Indeed, this is the very reason why he was stationed at the guns. A paper-picker is not needed and may run for cover during an air raid, but not a gunner. If his duty is to man an anti-aircraft gun, his leaving it is absence without leave to avoid a hazardous duty. ${ }^{58}$ His act is one of cowardice, not of prudence.

\footnotetext{
${ }^{87}$ Avins, op. cit. supra note 5I, at 122.

${ }^{88}$ Compare ETO 6997, Jennings, 17 ETO 309, 315 (1945), saying: "They did,
} 
As for the third airman, whether his act is one of prudence or cowardice depends upon whether any useful purpose will be served by continuing to load the bullets. If remaining at his place of duty is but a vain gesture of defiance or a risk without hope of military gain, withdrawal to cover is allowable prudence. If, however, the pilot might take the fighter into the air where bullets would be needed, then the risk is required, and desertion is the penalty for refusal.

In the final analysis, the question of whether absence without leave from a hazardous place of duty is desertion turns on elementary principles of the law of AWOL and, more particularly, on whether the absence is excused by the defense of mistake of fact on the part of authority..$^{50}$ If superior authority which ordered accused to the place of duty did not contemplate the hazards there, and would have permitted accused to seek shelter or safety had he known thereof, then it is a principle of AWOL law that he is permitted to leave the hazardous place. Not being absent without leave, he cannot therefore be a deserter. Viewed from this legal premise, the case of the soldier who left the truck is not indefensible, although its factual basis is questionable. On the other hand, when the hazards of the place were contemplated by superior authority and the duty enjoined notwithstanding those hazards, the AWOL defense does not apply. Absence to seek a place of refuge in this case is within the ban of the short desertion statute.

The above rule is simple of application, and most cases will fall readily on one side of the line or the other. However, the case of the soldier who escaped from the cellar when it was shelled represents a small group of cases for which it might be argued that a third category is necessary, viz.: a rule that absence without leave from a hazardous place of duty is AWOL only when the accused, although required to remain at the hazardous place, is performing no duty at all or no duty of sufficient significance to warrant a special deterrent to keep him there.

The mere fact that accused is physically inactive does not bring him within the above potential rule. A sentry is a prime example of

\footnotetext{
in fact successfully evade the performance of important combat duties during their absence. They showed an obvious lack of sense of duty and responsibility as soldiers," with ETO 8 104, Shearer, 19 ETO 17, I9 (1945), noting, "Accused was relieved of any duties with the gun section and was charged solely with the duty of cooking. At mealtime, their food was not prepared and accused's absence was then discovered," and on this basis deciding, in the former case, that the accused did commit short desertion, while in the latter case he did not.

${ }^{\circ}$ Avins, op. cit. note 51 , at $188-206$.
} 
one who performs a key service by merely being at his place of duty. Moreover, it may be vitally necessary to keep troops in reserve at a hazardous place, although the troops are only resting. ${ }^{.0}$ In the case of the prisoner in pre-trial confinement, however, he is awaiting processing only remotely connected with national defense. His absence to avoid the shelling should be considered as AWOL only on the ground that the hazardous place of duty does not arise from a duty which is of no significance.

Carving such an exception in the law of short desertion certainly has much to be said for it. The accused is required to remain at his place of duty notwithstanding the hazard, and having no defense to unauthorized departure, should be punished for it. But his duty, not being of the kind which is of sufficient significance to warrant a special penalty for forsaking it, nor of the kind to which the statute on short desertion was designed to bind him, should not be classified under the term of hazardous duty.

The above proposal, however, has one self-defeating flaw which forecloses its adoption. The whole theory of short desertion is that a mere AWOL penalty is insufficient to keep soldiers in hazardous places of duty, and a special deterrent is needed. To attempt to bind a soldier with an AWOL penalty, therefore, is to use too weak a chain for the purpose. The result of the proposed exception is that soldiers so covered will continue to absent themselves; the AWOL penalty, unable to serve as an effective deterrent, will become an idle gesture, and soldiers will be punished without benefit to anyone. Hence either a sufficient deterrent, such as the short desertion statute, should be used or none at all. Under this view, the rule that short desertion covers hazardous places of duty as well as inherently hazardous duty is commended not only by logic, but also by policy.

Application of this rule to the case of the pre-trial prisoner leaves little doubt that a temporary absence there should go unpunished. His

\footnotetext{
${ }^{80}$ See ETO 6079, Marchetti, 16 ETO $111,113-14$ (1945):

Accused initially absented himself from his organization at a time when it was occupying a secondary position on the Anzio beachhead some 1,000 yards from the front lines. Numerous casualties were being suffered at the time as the result of continuous and heavy shelling. . . . Shortly after he was returned to his company he again absented himself therefrom without authority. Although his unit was in a "rest area". at this time, it appears that such area was, a rest area more in name than in fact. The, area was on the Anzio beachhead, was subjected to occasional shelling, and was separated from the enemy lines by a distance of only a mile and a half at the closest point, and the enemy lines were nowhere more than ten miles distant.
} 
presence in the area of the shelling served no useful purpose, and, if he surrendered at the earliest opportunity and performed all other duties incumbent on one who takes advantage of a defense to an AWOL charge, his absence does not detract from the performance of duty by himself or others. Shelling is not a normal incident of pre-trial confinement, nor could it have been contemplated in this case. Since it is reasonable to suppose that if accused's presence was solely to await trial, he would have been moved to a safer area, the defense of mistake of authority has been made out. Although accused has left a hazardous place of duty, he is neither a deserter nor an abstentee without leave.

\section{Comparative Hazards}

Another problem for consideration is what the effect shall be of an absence to avoid a duty which is more hazardous than ones the accused is willing to perform. Put another way, the question exists whether an accused is a deserter when his AWOL is designed to avoid great hazards, but not all hazards. Can hazards be compared for this purpose, both with respect to duty inherently hazardous and to hazardous places of duty?

Of course, it is often "difficult to draw the line as to what was more hazardous duty than others," and it is not infrequently "impracticable to differentiate between various degrees of hazard." ${ }^{\text {"62 }}$ But often such a difference in degrees of hazard exist, ${ }^{63}$ and sometimes those differences in degree are quite marked. For example, statistics show that parachute jumping is not as dangerous as flying. ${ }^{64}$ Hence a serviceman who went AWOL to avoid flying as a member of a combat crew, but who expressed a willingness to become a paratrooper, would be seeking to trade his more hazardous duty for one less dangerous, although both fell within the rubric of "hazardous duty."

${ }^{01} 1949$ Hearings 1859 .

${ }^{02}$ Id. at 1596.

's 1949 Semate Hearings 114. See also the following from 1949 Hearings 1593:

d. Differentiation of degrees of hazard.-That hazards, both direct and career, vary so markedly according to weather conditions, time of day or night, terrain over which flights are made, types of planes flown, length of flight, nature of flight mission, physical and nervous condition of the pilot, etc., as to make impracticable an equitable determination of the degree of hazard, on a basis of duty assignment, sufficiently accurate to use as a basis of establishing flying pay....

1949 Senate Hearings 218 . See also the following from 1955 Hearings 67: "Whereas the paratrooper is charged an extra insurance premium of from 17 to 25 cents per month per thousand, the aviator must pay extra premiums ranging from $\$ 5.65$ to $\$ 28$ per month per thousand, depending upon variable factors such as age and number of hours flown." But see 1949 Hearings 1582. 
The same problem exists with reference to a dangerous place of duty. If the accused seeks a place of "comparative safety," is is he a deserter although his place of refuge is also fraught with danger of a lesser degree or kind?

The only case to discuss this problem answered the question in the affirmative. ${ }^{68}$ In that case, a board of review in the North African Theater of Operations held as follows:

That accused stayed in Nettuno and the rear area generally, instead of joining his organization ... warranted the conclusion that accused absented himself with the intent alleged. While accused was subjected to hazards by his presence at Nettuno, it is clear that it was far less hazardous than service with the combatant organization to which he was assigned. ${ }^{67}$

It is believed that the above decision states a sound rule of military law. If personnel were permitted to absent themselves to avoid a hazardous duty or hazardous place of duty, and defend against a desertion charge by seeking a less hazardous duty or place of duty, "shirkers" would naturally gravitate to places with as little danger as possible consistent with a showing of hazard. This result would be as pernicious as permitting them to go to places without danger. Since in time of war the number of dangerous places is multiplied, to permit this defense is to open a gaping loophole in the law of desertion, for many absentees seeking safety may be willing to trade a little danger to avoid a desertion penalty and may find such slightly dangerous spots readily available. Hence the rule properly is that absence without leave to avoid hazard is short desertion notwithstanding the fact that the accused during his absence incurs a lesser hazard.

\section{Conclusion}

The foregoing article has analyzed some of the problems incident to the application of the concept of "hazardous duty" in military desertion. It has attempted to show that a rational formulation of this concept consistent with both the protection of military needs and the .rights of servicemen can be made. It is believed that by applying the foregoing standards to the interpretation of the statute, the law of desertion can be rendered more certain and well-adapted to deter the type of conduct Congress sought to forbid.

\footnotetext{
${ }^{85}$ ETO 4702 , Petruso, 13 ETO 235, 237 (1945).

"NATO 3270 , Kissel, 5 NATO-MTO 21 (1944).

"Id. at 25 .
} 